Article

\title{
Stabilities of zeolite-supported Ni catalysts for dry reforming of methane
}

\author{
Anis H. FAKEEHA, Wasim U. KHAN, Ahmed S. AL-FATESH, Ahmed E. ABASAEED* \\ Chemical Engineering Department, College of Engineering, King Saud University, P.O. Box 800, Riyadh 11421, Saudi Arabia
}

\section{A R T I C L E I N F O}

Article history:

Received 26 October 2012

Accepted 8 February 2013

Published 20 April 2013

\section{Keywords:}

Carbon dioxide

Dry reforming

Methane

Nickel catalyst

H-ZSM-5 zeolite

Carbon deposition

\section{A B S T R A C T}

$\mathrm{Ni} / \gamma-\mathrm{Al}_{2} \mathrm{O}_{3}, \mathrm{Ni} / \mathrm{Y}$-zeolite, and $\mathrm{Ni} / \mathrm{H}-\mathrm{ZSM}-5$ catalysts were prepared using the incipient wetness impregnation method. Their catalytic performance in dry reforming of methane was studied. The fresh and used catalysts and deposited carbon were characterized using $\mathrm{H}_{2}$ temperature-programmed reduction, temperature-programmed oxidation, $\mathrm{N}_{2}$ adsorption-desorption, X-ray diffraction, and thermogravimetric analysis. The H-ZSM-5-supported Ni catalyst proved to be more stable than the other two catalysts, as it had the lowest carbon deposition.

(C) 2013, Dalian Institute of Chemical Physics, Chinese Academy of Sciences. Published by Elsevier B.V. All rights reserved.

\section{Introduction}

Synthesis gas, usually called syngas ( $\mathrm{CO}$ and $\left.\mathrm{H}_{2}\right)$, is industrially useful for making various value-added liquid hydrocarbons and oxygenates through the well-known Fischer-Tropsch process $[1,2]$. Syngas can be produced through the following catalytic processes: partial oxidation, steam reforming, and dry reforming of methane [3,4]. Dry reforming is attracting increasing attention as it consumes two of the most important greenhouse gases $\left(\mathrm{CH}_{4}\right.$ and $\left.\mathrm{CO}_{2}\right)$ to produce syngas [5-7]. The catalyst support plays an important role in coking resistance of metal particles and may even participate in the catalytic activity [8]. Zeolites are attractive supports for $\mathrm{CO}_{2}$ reforming of $\mathrm{CH}_{4}$ because they have well-defined structures, high surface areas, high thermal stabilities, and high affinities for $\mathrm{CO}_{2}$; these properties are expected to enhance the catalyst selectivity and stability $[9,10]$. It is also well known that zeolite supports have the potential to deliver very high metal dispersions and to provide stable systems. These excellent properties, combined with a low potential for support-metal interactions and superior coking resistance, make zeolites important catalyst supports in the $\mathrm{CO}_{2}$ reforming of $\mathrm{CH}_{4}$.

$\mathrm{Ni}$ catalysts are used industrially for both steam reforming and dry reforming reactions because of their fast turnover rates, ready availability, and low costs [11]. A major problem encountered in Ni-based catalysts is carbon deposition on the surface, which leads to deactivation and blockage of reactor tubes. Besides coke formation, sintering of metal particles can also contribute to loss of catalytic activity [12,13]. Materials traditionally used as supports are insulating oxides such as $\mathrm{SiO}_{2}, \mathrm{Al}_{2} \mathrm{O}_{3}, \mathrm{~V}_{2} \mathrm{O}_{5}$, and $\mathrm{TiO}_{2}$, and various types of zeolites have also been tested $[14,15]$. Recently, the activities of different zeolite-supported $\mathrm{Ni}$ catalysts for $\mathrm{CH}_{4}$ reforming with $\mathrm{CO}_{2}$ have been investigated $[4,16]$. Among these, MFI- and USY-type zeolites greatly improve the stability and selectivity of the reaction because they have suitable properties (e.g., microporous struc-

*Corresponding author. Tel: +966-1-4676856; Fax: +966-1-4678770; E-mail: abasaeed@ksu.edu.sa DOI: 10.1016/S1872-2067(12)60554-3 | http://www.sciencedirect.com/science/journal/18722067 | Chin. J. Catal.,Vol. 34, No. 4, April 2013 
tures, high surface areas, and high affinities for $\mathrm{CO}_{2}$ adsorption) for catalyst supports in reforming reactions [17-19].

In this study, the stabilities and catalytic activities of three $\mathrm{Ni}$ catalysts, supported on alumina, Y-zeolite, and H-ZSM-5 zeolite, were investigated. Various characterization techniques were used to quantify the carbon deposition.

\section{Experimental}

\subsection{Catalyst preparation}

$\gamma-\mathrm{Al}_{2} \mathrm{O}_{3}$ (SA-6175) with a Brunauer-Emmett-Teller (BET) area of $230 \mathrm{~m}^{2} / \mathrm{g}$, Y-zeolite (CBV500) with a BET area of 750 $\mathrm{m}^{2} / \mathrm{g}$, and H-ZSM-5 (CBV2030E) with a BET area of $405 \mathrm{~m}^{2} / \mathrm{g}$ were used as supports. A series of Ni-based catalysts (the $\mathrm{Ni}$ content was fixed at $5 \mathrm{wt} \%$ ) were prepared on the supports. The catalysts were prepared by the incipient wetness impregnation method using $\mathrm{Ni}\left(\mathrm{NO}_{3}\right)_{2} \cdot 6 \mathrm{H}_{2} \mathrm{O}$ as the metal precursor. After impregnation, the catalysts were dried overnight at 120 ${ }^{\circ} \mathrm{C}$ and then calcined at different temperatures, namely 500 , 700 , and $900^{\circ} \mathrm{C}$, for $3 \mathrm{~h}$.

\subsection{Catalyst characterization}

Phase identification of the prepared catalysts was carried out using X-ray diffraction (XRD), with $\mathrm{Cu} K_{\alpha}$ radiation, in the $2 \theta$ range $0^{\circ}-80^{\circ}$ on a Unisantis XMD-300 diffractometer. $\mathrm{N}_{2}$ adsorption-desorption isotherms were measured to examine the porous properties of each catalyst. The measurements were carried out using a Micromeritics ASAP 2020 instrument. Before the analyses, all the samples were pretreated under vacuum conditions at $200{ }^{\circ} \mathrm{C}$ for $12 \mathrm{~h}$. Temperature-programmed reduction (TPR) was carried out using a Chemisorb Micromeritics 2920 instrument to monitor the metal oxide reduction. The sample was first pretreated in a flow of helium at 200 ${ }^{\circ} \mathrm{C}$ and then reduced under a flow (20 ml/min) of a $5.32 \%$ $\mathrm{H}_{2} / \mathrm{N}_{2}$ mixture. The sample was heated from 60 to $900{ }^{\circ} \mathrm{C}$ at a heating rate of $10{ }^{\circ} \mathrm{C} / \mathrm{min}$. After reaction at $700{ }^{\circ} \mathrm{C}$ for $9 \mathrm{~h}$, temperature-programmed oxidation (TPO) was performed to study the reactivity of the carbon species by oxidizing the sample under a flow of air while the temperature was increased from room temperature to $800{ }^{\circ} \mathrm{C}$, linearly with time, at a heating rate of $10^{\circ} \mathrm{C} / \mathrm{min}$. Thermogravimetric analysis (TGA) was carried out to determine the amount of carbon deposited on the catalysts after use in the $\mathrm{CO}_{2}$ reforming of $\mathrm{CH}_{4}$. The analyses were performed using a TGA/differential thermal analysis (EXSTAR SII TG/DTA 7300) instrument; $10 \mathrm{mg}$ of each sample were introduced into a platinum microbalance pan in an air atmosphere, and the heating rate was $10{ }^{\circ} \mathrm{C} / \mathrm{min}$.

\subsection{Catalytic tests}

The $\mathrm{CO}_{2}$ reforming reaction of $\mathrm{CH}_{4}$ was carried out in a continuous-flow reactor, at a pressure of $101.3 \mathrm{kPa}$ and different temperatures $\left(500,600\right.$, and $\left.700{ }^{\circ} \mathrm{C}\right)$, with a constant stoichiometric feed mixture of $\mathrm{CH}_{4}$ and $\mathrm{CO}_{2}$ (1:1) and a total flow rate of $36 \mathrm{ml} / \mathrm{min}$. Samples of $0.6 \mathrm{~g}$ of catalyst were used for each catalytic test. The data were collected every $30 \mathrm{~min}$ on stream for $9 \mathrm{~h}$. The reaction products were analyzed using an on-line gas chromatograph (Varian Star 3400 CX). The details of the experimental setup and procedure have been given in previous publications $[20,21]$.

\section{Results and discussion}

\subsection{Catalytic activity}

The catalytic performances of $5 \mathrm{wt} \% \mathrm{Ni} / \gamma-\mathrm{Al}_{2} \mathrm{O}_{3}, 5 \mathrm{wt} \%$ $\mathrm{Ni} / Y-z e o l i t e$ (denoted $\mathrm{Ni} / \mathrm{Y}$ ), and $5 \mathrm{wt} \% \mathrm{Ni} / \mathrm{H}-\mathrm{ZSM}-5$ catalysts were investigated at different calcination and reaction temperatures. Table 1 shows the effects of the calcination and reaction temperatures on $\mathrm{CH}_{4}$ and $\mathrm{CO}_{2}$ conversions for the $\mathrm{Ni} / \gamma-\mathrm{Al}_{2} \mathrm{O}_{3}$, $\mathrm{Ni} / \mathrm{Y}$, and Ni/H-ZSM- 5 catalysts. It can be seen that the effect of the reaction temperature on the catalytic activity is more pronounced than the effect of the calcination temperature. For all calcination temperatures, an increase in the reaction temperature resulted in higher conversions of $\mathrm{CH}_{4}$ and $\mathrm{CO}_{2}$, confirming the endothermicity of the reaction.

It can be seen from Table 1 that the $\mathrm{Ni} / \gamma-\mathrm{Al}_{2} \mathrm{O}_{3}$ catalysts at all calcination and reaction temperatures, and the Ni/H-ZSM-5 catalysts at all calcination temperatures and a reaction temperature of $700{ }^{\circ} \mathrm{C}$, showed higher conversions of $\mathrm{CO}_{2}$ than of $\mathrm{CH}_{4}$. A similar trend was observed for the $\mathrm{Ni} / \mathrm{Y}$ catalysts for calcination temperatures of $500{ }^{\circ} \mathrm{C}$ (at a reaction temperature of 500 ${ }^{\circ} \mathrm{C}$ ), $700{ }^{\circ} \mathrm{C}$ (at reaction temperatures of 500 and $600{ }^{\circ} \mathrm{C}$ ), and $900{ }^{\circ} \mathrm{C}$ (at a reaction temperature of $500{ }^{\circ} \mathrm{C}$ ). $\mathrm{A} \mathrm{CO}_{2}$ conversion greater than that of $\mathrm{CH}_{4}$ is the result of the reverse water shift reaction, which consumes the formed $\mathrm{H}_{2}$, resulting in an $\mathrm{H}_{2} / \mathrm{CO}$ ratio less than one. For the $\mathrm{Ni} / \mathrm{H}-\mathrm{ZSM}-5$ catalysts, for all calcination temperatures and reaction temperatures of 500 and 600

Table 1

Activity tests for $\mathrm{Ni} / \gamma-\mathrm{Al}_{2} \mathrm{O}_{3}, \mathrm{Ni} / \mathrm{Y}$, and $\mathrm{Ni} / \mathrm{H}-\mathrm{ZSM}-5$ catalysts with different calcination temperatures.

\begin{tabular}{|c|c|c|c|c|c|c|c|c|c|c|}
\hline \multirow{2}{*}{$\begin{array}{l}\text { Calcination } \\
\text { temperature }\left({ }^{\circ} \mathrm{C}\right)\end{array}$} & \multirow{2}{*}{$\begin{array}{c}\text { Reaction } \\
\text { temperature }\left({ }^{\circ} \mathrm{C}\right)\end{array}$} & \multicolumn{3}{|c|}{ Conversion of $\mathrm{CH}_{4}(\%)$} & \multicolumn{3}{|c|}{ Conversion of $\mathrm{CO}_{2}(\%)$} & \multicolumn{3}{|c|}{$\mathrm{H}_{2} / \mathrm{CO}$} \\
\hline & & $\mathrm{Ni} / \gamma-\mathrm{Al}_{2} \mathrm{O}_{3}$ & $\mathrm{Ni} / \mathrm{Y}$ & $\mathrm{Ni} / \mathrm{H}-\mathrm{ZSM}-5$ & $\mathrm{Ni} / \gamma-\mathrm{Al}_{2} \mathrm{O}_{3}$ & $\mathrm{Ni} / \mathrm{Y}$ & $\mathrm{Ni} / \mathrm{H}-\mathrm{ZSM}-5$ & $\mathrm{Ni} / \gamma-\mathrm{Al}_{2} \mathrm{O}_{3}$ & $\mathrm{Ni} / \mathrm{Y}$ & $\mathrm{Ni} / \mathrm{H}-\mathrm{ZSM}-5$ \\
\hline \multirow[t]{3}{*}{500} & 500 & 18.1 & 16.3 & 24.9 & 18.7 & 18.0 & 19.3 & 0.60 & 0.74 & 1.26 \\
\hline & 600 & 46.7 & 59.7 & 63.7 & 51.1 & 50.4 & 45.2 & 0.81 & 1.20 & 1.31 \\
\hline & 700 & 80.1 & 70.8 & 78.2 & 82.9 & 67.4 & 86.3 & 0.96 & 0.97 & 0.97 \\
\hline \multirow[t]{3}{*}{700} & 500 & 10.2 & 14.9 & 21.9 & 16.6 & 15.8 & 18.1 & 0.40 & 0.66 & 1.29 \\
\hline & 600 & 42.0 & 37.6 & 58.1 & 49.3 & 41.7 & 36.2 & 0.68 & 1.20 & 1.38 \\
\hline & 700 & 79.8 & 65.2 & 77.5 & 81.5 & 64.4 & 83.2 & 0.94 & 0.97 & 0.98 \\
\hline \multirow[t]{3}{*}{900} & 500 & 10.8 & 13.8 & 24.1 & 17.6 & 14.7 & 18.2 & 0.46 & 0.98 & 1.42 \\
\hline & 600 & 42.1 & 45.0 & 61.5 & 49.8 & 31.9 & 37.4 & 0.71 & 1.10 & 1.49 \\
\hline & 700 & 81.6 & 70.7 & 79.1 & 84.6 & 66.4 & 81.7 & 0.95 & 0.96 & 0.97 \\
\hline
\end{tabular}


Table 2

Coke deposition on, and surface areas of, $\mathrm{Ni} / \gamma-\mathrm{Al}_{2} \mathrm{O}_{3}, \mathrm{Ni} / \mathrm{Y}$, and $\mathrm{Ni} / \mathrm{H}-\mathrm{ZSM}-5$ catalysts.

\begin{tabular}{|c|c|c|c|c|c|c|c|c|c|}
\hline \multirow{3}{*}{ Catalyst } & \multirow{3}{*}{$\begin{array}{c}\text { Calcination } \\
\text { temperature }\left({ }^{\circ} \mathrm{C}\right)\end{array}$} & \multicolumn{4}{|c|}{ Conversion (\%) } & \multirow{3}{*}{$\mathrm{DF}^{\mathrm{a}}(\%)$} & \multirow{3}{*}{ Coke $^{b}(w t \%)$} & \multicolumn{2}{|c|}{$A_{\mathrm{BET}} /\left(\mathrm{m}^{2} / \mathrm{g}\right)$} \\
\hline & & \multicolumn{2}{|c|}{ Initial } & \multicolumn{2}{|c|}{ Final (after $9 \mathrm{~h}$ ) } & & & Before & After \\
\hline & & $\mathrm{CH}_{4}$ & $\mathrm{CO}_{2}$ & $\mathrm{CH}_{4}$ & $\mathrm{CO}_{2}$ & & & reaction & reaction \\
\hline \multirow[t]{3}{*}{$\mathrm{Ni} / \gamma-\mathrm{Al}_{2} \mathrm{O}_{3}$} & 500 & 80.1 & 82.9 & 78.1 & 76.2 & 2.5 & 8.0 & 208.7 & 170.7 \\
\hline & 700 & 79.8 & 81.5 & 77.4 & 75.4 & 3.0 & 9.8 & 189.9 & 161.8 \\
\hline & 900 & 81.6 & 84.6 & 79.7 & 78.7 & 2.3 & 7.8 & 146.2 & 138.0 \\
\hline \multirow[t]{3}{*}{$\mathrm{Ni} / \mathrm{Y}$} & 500 & 70.8 & 67.4 & 65.8 & 66.3 & 7.1 & 13.5 & 572.3 & 497.1 \\
\hline & 700 & 65.2 & 64.4 & 61.8 & 63.4 & 5.2 & 13.1 & 572.7 & 488.4 \\
\hline & 900 & 70.7 & 66.4 & 67.8 & 65.3 & 4.1 & 9.4 & 562.5 & 525.9 \\
\hline \multirow[t]{3}{*}{$\mathrm{Ni} / \mathrm{H}-\mathrm{ZSM}-5$} & 500 & 78.2 & 86.3 & 76.8 & 85.3 & 1.8 & 3.3 & 334.3 & 317.4 \\
\hline & 700 & 77.5 & 83.2 & 75.9 & 79.4 & 2.1 & 6.8 & 327.1 & 305.6 \\
\hline & 900 & 79.1 & 81.7 & 76.8 & 78.2 & 2.9 & 7.7 & 270.4 & 259.3 \\
\hline
\end{tabular}

Reaction temperature $700^{\circ} \mathrm{C} .{ }^{\mathrm{a}} \mathrm{DF}=(($ Initial conversion - Final conversion $) /$ Initial conversion $) \times 100 \%$. ${ }^{\mathrm{b}}$ Determined by TGA.

${ }^{\circ} \mathrm{C}$, and for the $\mathrm{Ni} / \mathrm{Y}$ catalysts, for all calcination temperatures and a reaction temperature of $600{ }^{\circ} \mathrm{C}$, the higher $\mathrm{CH}_{4}$ conversion compared to $\mathrm{CO}_{2}$ conversion could be attributed to thermal cracking of $\mathrm{CH}_{4}$, leading to coke formation and, consequently, an $\mathrm{H}_{2} / \mathrm{CO}$ ratio greater than one [21].

The data in Table 1 also shows the effect of calcination temperature on catalytic activity. It can be seen that for the $\mathrm{Ni} / \gamma-\mathrm{Al}_{2} \mathrm{O}_{3}, \mathrm{Ni} / \mathrm{Y}$, and $\mathrm{Ni} / \mathrm{H}-\mathrm{ZSM}-5$ catalysts, at low reaction temperatures $\left(500-600^{\circ} \mathrm{C}\right)$, the catalytic activity is higher for a calcination temperature of $500{ }^{\circ} \mathrm{C}$, whereas at a higher reaction temperature $\left(700{ }^{\circ} \mathrm{C}\right)$, a calcination temperature of $900{ }^{\circ} \mathrm{C}$ leads to high activity. These differences could plausibly be attributed to phase formation in the catalysts.

\subsection{Catalytic stability}

Time-on-stream conversions, amounts of coke deposited, and the surface areas of the fresh and spent catalysts are presented in Table 2. It can be seen that both $\mathrm{CH}_{4}$ and $\mathrm{CO}_{2}$ conversions decreased over a time period of $9 \mathrm{~h}$. The main reason for this deactivation of the catalysts was carbon deposition.

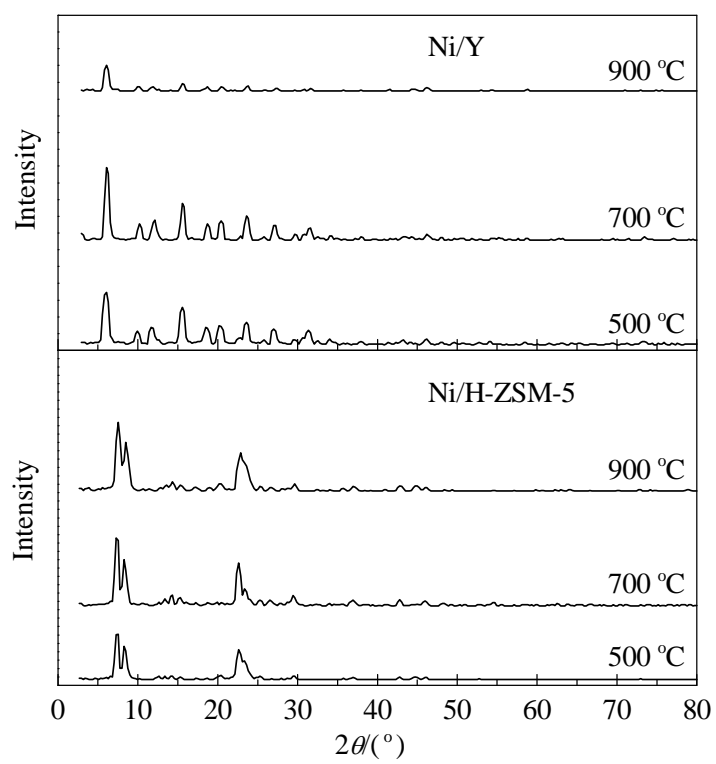

Fig. 1. XRD patterns of fresh $\mathrm{Ni} / \mathrm{Y}$ and $\mathrm{Ni} / \mathrm{H}-\mathrm{ZSM}-5$ catalysts with different calcination temperatures.
Based on thermodynamics, at a high reaction temperature $\left(>650{ }^{\circ} \mathrm{C}\right.$ ) coke is expected to be formed mainly via $\mathrm{CH}_{4}$ decomposition (reaction (1) below). TGA was used to estimate the amounts of carbon deposited. It is clear from Table 2 that the average amount of carbon deposited on Ni/H-ZSM-5 (5.9 wt $\%$ ) was much less than the amounts deposited on $\mathrm{Ni} / \gamma-\mathrm{Al}_{2} \mathrm{O}_{3}$ (8.5 wt \%) and Ni/Y (12.0 wt\%). This proves the higher stability of the Ni/H-ZSM-5 catalyst and lower carbon deposition on its surface; the stabilities of the catalysts are in the order $\mathrm{Ni} / \mathrm{H}-\mathrm{ZSM}-5>\mathrm{Ni} / \gamma-\mathrm{Al}_{2} \mathrm{O}_{3}>\mathrm{Ni} / \mathrm{Y}$.

\subsection{Catalyst characterization}

Figure 1 shows the XRD patterns for fresh $\mathrm{Ni} / \mathrm{Y}$ and $\mathrm{Ni} / \mathrm{H}-\mathrm{ZSM}-5$ catalysts calcined at different temperatures. It can be seen that $\mathrm{Ni} / \mathrm{Y}$ and $\mathrm{Ni} / \mathrm{H}-\mathrm{ZSM}-5$ passivated catalysts calcined at 500,700 , and $900{ }^{\circ} \mathrm{C}$ showed the diffraction peaks of $\mathrm{NiO}(111), \mathrm{NiO}(200)$, and $\mathrm{NiO}(220)$ at $2 \theta=37.2^{\circ}, 44^{\circ}$, and $62.5^{\circ}$ (JCPDS 04-850), respectively.

Figure 2 shows the elemental analyses of the spent catalysts determined using energy-dispersive spectroscopy (EDS). The

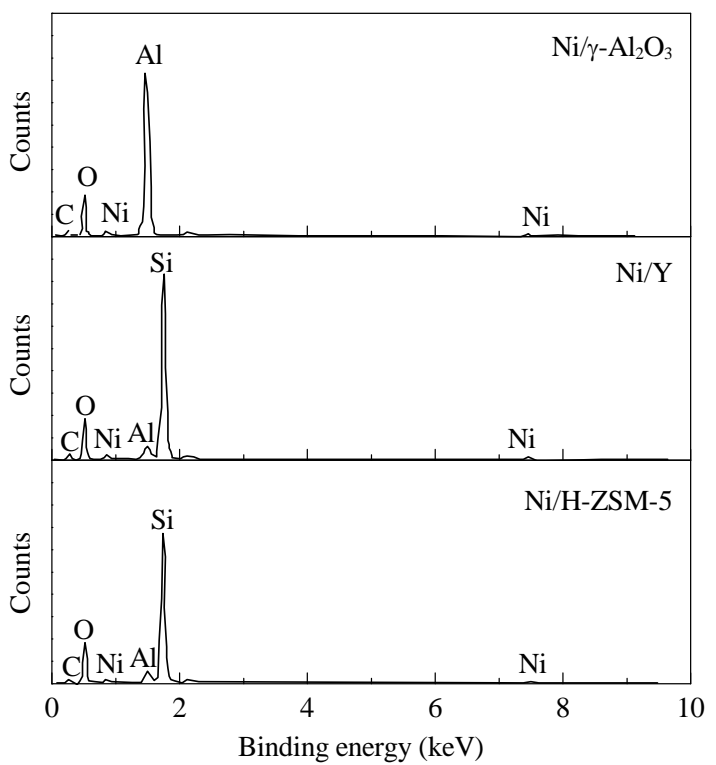

Fig. 2. EDS of carbon deposited on used $\mathrm{Ni} / \gamma-\mathrm{Al}_{2} \mathrm{O}_{3}, \mathrm{Ni} / \mathrm{Y}$ and $\mathrm{Ni} / \mathrm{H}-\mathrm{ZSM}-5$ catalysts. 


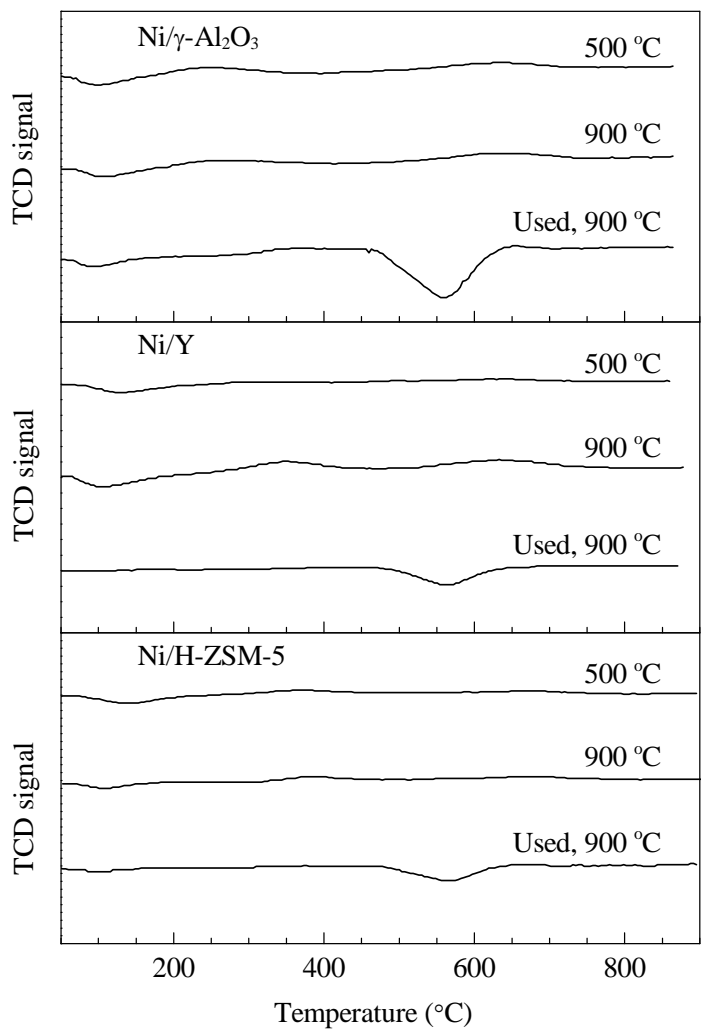

Fig. 3. TPO results for $\mathrm{Ni} / \gamma-\mathrm{Al}_{2} \mathrm{O}_{3}, \mathrm{Ni} / \mathrm{Y}$, and $\mathrm{Ni} / \mathrm{H}-\mathrm{ZSM}-5$ catalysts at different calcination temperatures.

figure shows carbon formation on the catalyst surfaces (with $\mathrm{Ni} / \mathrm{H}-\mathrm{ZSM}-5$ having the lowest amount). This deposition of carbon is in agreement with the TGA results listed in Table 2.

TPO is a useful technique for investigating carbon deposition in more detail. TPO provides important information regarding accumulated carbon species, and their structures, amounts, and compositions. It is widely recognized that amorphous carbon species can be combusted at lower temperatures than crystalline species, i.e., the oxidation temperature increases with increasing degree of crystallinity. Figure 3 displays the signals of generated $\mathrm{CO}_{2}$ for the three catalysts as a function of temperature. The spent catalysts calcined at $900{ }^{\circ} \mathrm{C}$ showed a significant $\mathrm{CO}_{2}$ release peak at $450-620^{\circ} \mathrm{C}$, which can be related to combustion of different crystalline forms of carbon, e.g., carbon nanofibers and carbon nanotubes. Generally speaking, the most probable reactions leading to carbon formation during reforming processes are those shown in Equations (1)-(4):

$$
\begin{aligned}
\mathrm{CH}_{4} & \leftrightarrow 2 \mathrm{H}_{2}+\mathrm{C} \\
2 \mathrm{CO} & \leftrightarrow \mathrm{CO}_{2}+\mathrm{C} \\
\mathrm{CO}+\mathrm{H}_{2} & \leftrightarrow \mathrm{H}_{2} \mathrm{O}+\mathrm{C} \\
\mathrm{CO}_{2}+2 \mathrm{H}_{2} & \leftrightarrow 2 \mathrm{H}_{2} \mathrm{O}+\mathrm{C}
\end{aligned}
$$

Reactions (2), (3), and (4) are favored at low temperatures $\left(<575{ }^{\circ} \mathrm{C}\right) ; \mathrm{CH}_{4}$ decomposition (reaction (1)) takes place at higher temperatures, and is therefore the prime cause of carbon formation [22].

Figure 4 presents the TPR results for fresh and used $\mathrm{Ni} / \gamma-\mathrm{Al}_{2} \mathrm{O}_{3}, \mathrm{Ni} / \mathrm{Y}$, and $\mathrm{Ni} / \mathrm{H}-\mathrm{ZSM}-5$ catalysts. The fresh $\mathrm{Ni} / \gamma-\mathrm{Al}_{2} \mathrm{O}_{3}$ catalysts calcined at 500 and $900{ }^{\circ} \mathrm{C}$ showed three

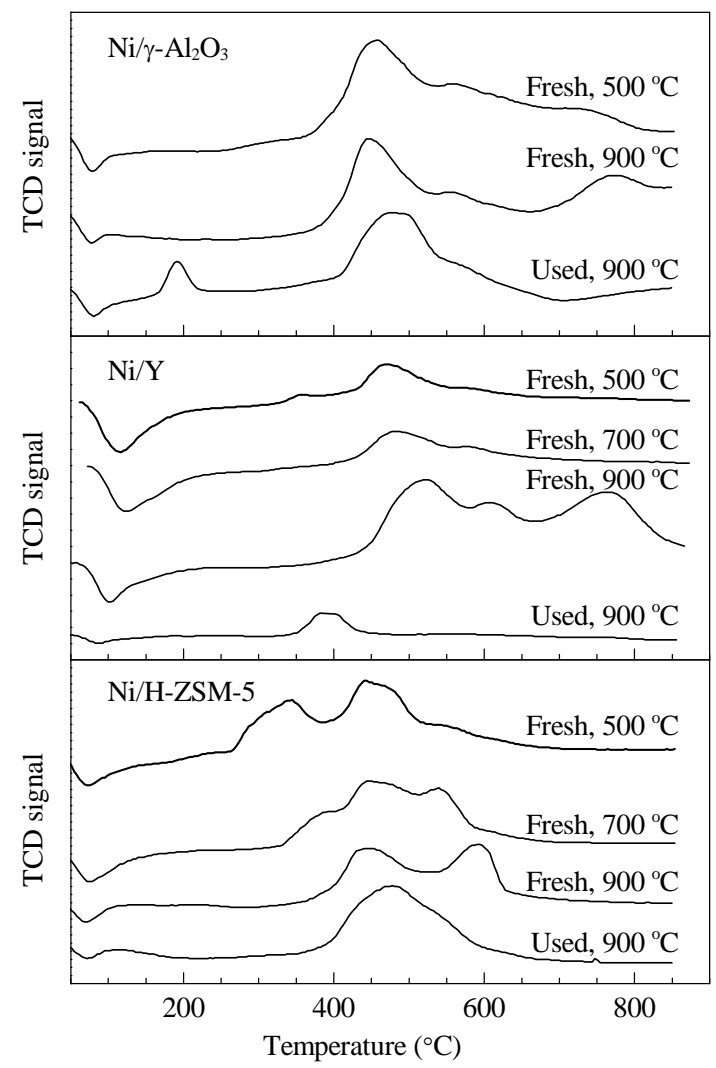

Fig. 4. TPR results for $\mathrm{Ni} / \gamma-\mathrm{Al}_{2} \mathrm{O}_{3}, \mathrm{Ni} / \mathrm{Y}$, and $\mathrm{Ni} / \mathrm{H}-\mathrm{ZSM}-5$ at different calcination temperatures.

peaks in the temperature range $420-800{ }^{\circ} \mathrm{C}$, and the fresh $\mathrm{Ni} / \mathrm{Y}$ catalysts calcined at 500,700 , and $900{ }^{\circ} \mathrm{C}$ showed three peaks in the temperature range $500-800{ }^{\circ} \mathrm{C}$. The fresh Ni/H-ZSM- 5 catalyst calcined at $500{ }^{\circ} \mathrm{C}$ showed two peaks, at 350 and 470 ${ }^{\circ} \mathrm{C}$, and a shoulder at $575^{\circ} \mathrm{C}$. The low-temperature peaks can be assigned to $\mathrm{NiO}$ reduction as a result of very low metal-support interactions, and the high-temperature peak is assigned to reduction of NiO particles with high interaction with the support. The peak for the fresh $\mathrm{Ni} / \gamma-\mathrm{Al}_{2} \mathrm{O}_{3}$ catalyst calcined at $900{ }^{\circ} \mathrm{C}$ at around $800{ }^{\circ} \mathrm{C}$ is attributed to reduction of spinel $\mathrm{NiAl}_{2} \mathrm{O}_{4}$. For the fresh $\mathrm{Ni} / \mathrm{Y}$ catalyst calcined at $900{ }^{\circ} \mathrm{C}$, the peak at $750{ }^{\circ} \mathrm{C}$ can be attributed to the reduction of $\mathrm{Ni}^{2+}$ hexagonal prisms, and for the fresh Ni/H-ZSM- 5 catalyst calcined at $900^{\circ} \mathrm{C}$, the peak at around $600^{\circ} \mathrm{C}$ can be related to $\mathrm{NiO}$ particles of a different size. In contrast, the $\mathrm{Ni} / \gamma-\mathrm{Al}_{2} \mathrm{O}_{3}, \mathrm{Ni} / \mathrm{Y}$, and $\mathrm{Ni} / \mathrm{H}-\mathrm{ZSM}-5$ spent catalysts showed only one peak, in the temperature range 300-600 ${ }^{\circ} \mathrm{C}$, which can be attributed to a methanation reaction, i.e. the reaction of $\mathrm{H}_{2}$ with carbon deposited on the catalyst surface (reverse of reaction (1) above).

\section{Conclusions}

$\mathrm{CO}_{2}$ reforming of $\mathrm{CH}_{4}$ is efficiently catalyzed by supported $\mathrm{Ni}$ catalysts. The activity towards $\mathrm{CH}_{4}$ conversion was found to depend on the nature of the support material. $\mathrm{H}_{2} / \mathrm{CO}$ ratios close to unity and lower carbon deposition leading to high stability were obtained for Ni/H-ZSM-5 catalysts. These findings were confirmed using XRD, EDS, TPO, and TPR techniques. 


\section{Graphical Abstract}

Chin. J. Catal., 2013, 34: 764-768 doi: 10.1016/S1872-2067(12)60554-3

Stabilities of zeolite-supported Ni catalysts for dry reforming of methane

Anis H. FAKEEHA, Wasim U. KHAN, Ahmed S. AL-FATESH,

Ahmed E. ABASAEED*

King Saud University, Saudi Arabia

In dry reforming of methane, the Ni catalyst supported on H-ZSM-5 zeolite was found to be more stable than those supported on alumina or Y-zeolite.

\section{Acknowledgements}

The authors extend their appreciation to the Deanship of Scientific Research at KSU for funding the work through the research group Project \# RGP-VPP-119.

\section{References}

[1] Shi C, Zhang P. Appl Catal B, 2011, 115-116: 190

[2] Bradford M C J, Vannice M A, Ruckenstein E. Catal Rev-Sci Eng, 1999, 41: 1

[3] Choudhary T V, Choudhary V R. Angew Chem, Int Ed, 2008, 47: 1828

[4] Frontera P, Aloise A, Macario A, Crea F, Antonucci P L, Giordano G, Nagy J B. Res Chem Intermediat, 2011, 37: 267

[5] Andonova S, de Avila C N, Arishtirova K, Bueno J M C, Damyanova B S. Appl Catal B, 2011, 105: 346

[6] Al-Fatesh A S A, Fakeeha A H. Res J Chem Environ, 2011, 15: 259

[7] Laosiripojana N, Assabumrungrat S. Appl Catal B, 2005, 60: 107

[8] Luengnaruemitchai A, Kaengsilalai A. Chem Eng J, 2008, 144: 96

[9] Frontera P, Aloise A, Macario A, Antonucci P L, Crea F, Giordano G,
Nagy J B. Top Catal, 2010, 53: 265

[10] Halliche D, Cherifi O, Taarit Y B, Auroux A. Kinet Catal, 2008, 49: 667

[11] Wang S, Lu G Q M. Appl Catal B, 1998, 16: 269

[12] Bhat R N, Sachtler W M H. Appl Catal A, 1997, 150: 279

[13] Tsipouriari V A, Efstathiou A M, Zhang Z L, Verykios X E. Catal Today, 1994, 21: 579

[14] Rostrup-Nielsen J R, Sehested J, Nørskov J K. Adv Catal, 2002, 47: 65

[15] Ross J R H. Catal Today, 2005, 100: 151

[16] Kaengsilalai A, Luengnaruemitchai A, Jitkarnka S, Wongkasemjit S. J Power Sources, 2007, 165: 347

[17] Nimwattanakul W, Luengnaruemitchai A, Jitkarnka S. Int J Hydrogen Energy, 2006, 31: 93

[18] Wang K, Li X, Ji S, Sun S, Ding D, Li C. Stud Surf Sci Catal, 2007, 167: 367

[19] Chang J-S, Park S-E, Chon H. Appl Catal A, 1996, 145: 111

[20] Al-Fatesh A S A, Fakeeha A H, Abasaeed A E. Chin J Catal (催化学 报), 2011, 32: 1604

[21] Al-Fatesh A S A, Ibrahim A A, Fakeeha A H, Soliman M A, Siddiqui M R H, Abasaeed A E. Appl Catal A, 2009, 364: 150

[22] Nikoo M K, Amin N A S. Fuel Process Technol, 2011, 92: 678 